Original Research Paper

\title{
Evaluation of Alternative Cropping and Nutrient Management Systems with Soil and Water Assessment Tool for the Raccoon River Watershed Master Plan
}

\author{
${ }^{1}$ Philip Gassman, ${ }^{2}$ Manoj Jha, ${ }^{3}$ Calvin Wolter and ${ }^{4}$ Keith Schilling \\ ${ }^{I}$ Department of Economics, Center for Agricultural and Rural Development, Iowa State University, Ames, IA, USA \\ ${ }^{2}$ Department of Civil, Architectural and Environmental Engineering, North Carolina A\&T University, Greensboro, NC, USA \\ ${ }^{3}$ Iowa Department of Natural Resources, 502 E 9th Street, Des Moines, IA 50319, USA \\ ${ }^{4}$ Iowa Geological Survey, Department of Earth and Environmental Sciences, IIHR, \\ 115 Trowbridge Hall, Iowa City, IA 52242, USA
}

Article history

Received: 27-02-2015

Revised: $13-06-2015$

Accepted: 01-07-2015

Corresponding author:

Philip Gassman

Department of Economics, Center

for Agricultural and Rural

Development, Iowa State

University, Ames, IA, USA

Email: pwgassma@iastate.edu

\begin{abstract}
Soil and Water Assessment Tool (SWAT) ecohydrological model was used to assess a suite of adaptive nutrient management, alternative cropping system and combination scenarios in support of a Master Plan that was developed to help guide policy makers, land owners and other stakeholders in improving water quality for the $9,400 \mathrm{~km}^{2}$ Raccoon River watershed in west central Iowa, located in the Corn Belt region of the United States. Calibration and validation of SWAT showed that the model was able to accurately replicate most streamflow and pollutant loss conditions, with $\mathrm{r}^{2}$ and Nash-Sutcliffe modeling Efficiency (NSE) statistics exceeding 0.5 for the majority of indicators. The largest reduction in predicted nitrate losses at the overall watershed scale for the adaptive nutrient management scenarios was slightly over $12 \%$, in response to a scenario in which $100 \%$ of the anhydrous ammonia fertilizer application was applied in the watershed four weeks after planting of corn. Considerably larger impacts on nitrate loss and other sediment and nutrient indicators, with some reductions exceeding $50 \%$, were predicted for scenarios representing widescale conversion of corn-soybean rotations to six-year rotation of Corn-Soybean-Corn-Alfalfa-Alfalfa-Alfalfa (CSCAAA) or combinations of adaptive nutrient management, conversion to CSCAAA rotations and the insertion of a rye cover crop on a portion of the area managed with corn and soybean within the CSCAAA rotations.
\end{abstract}

Keywords: SWAT Model, Water Quality, Nutrient Management Practices, Extended Rotations, Winter Cover Crops

\section{Introduction}

Many streams and other water bodies located in intensive agricultural production regions in the Upper Mississippi River Basin (UMRB) are characterized by pervasive water quality problems that now span decades. A classic example is the Raccoon River Watershed (RRW) located in west central Iowa, which has been impacted by elevated levels of nitrogen, phosphorus, sediment and bacteria pollutants during recent decades, primarily from nonpoint sources (Hatfield et al., 2009; Jha et al., 2010a; Schilling et al., 2008b). Two segments of the Raccoon River have officially been identified as impaired by nitrate-nitrogen (nitrate) and three segments have been identified as impaired by the pathogens indicator E. coli bacteria (Schilling et al., 2008a; Jha et al., 2010b). Nitrate concentrations were found to exceed the Maximum Contaminant Level (MCL) standard of $10 \mathrm{mg} / \mathrm{l}$ for drinking water at the Des Moines Water Works (DMWW) intake $32.3 \%$ of the time from 1996 to 2005 (Jha et al., 2010a). The DMWW installed the world's largest nitrate removal facility in 1991 (Hatfield et al., 2009) which costs $\$ 7,000$ per day when activated (DMWW, 2015).

The Total Maximum Daily Load (TMDL) target for nitrate in the Raccoon River was established at $9.5 \mathrm{mg}$ 


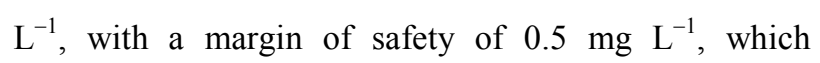
requires that stream nitrate concentrations do not exceed the target level for the entire range of streamflow (Schilling et al., 2008a). A load duration curve approach was used to establish this TMDL; it was estimated that a $48.1 \%$ reduction in nitrate loads is needed for compliance with the TMDL. The requirement for such a massive reduction in nitrate loss underscores the need for a multi-pronged approach to address these challenging water quality problems, as addressed in detail in a Raccoon River Master Plan that was developed for the watershed (Agren, 2011).

The simulation analysis presented here was conducted in support of the Master Plan development and is intended to provide additional insights in how widespread adoption of a selected set of alternative nutrient and cropping system practices could potentially impact RRW in-stream water quality. The study was performed with the Soil and Water Assessment Tool (SWAT) watershed-scale ecohydrological model (Arnold et al., 1998; Arnold and Fohrer, 2005; Williams et al., 2008) which has been extensively used to simulate the effects of land use change, climate variation, alternative cropping systems, best management practices and other scenarios on the hydrology and/or water quality of hundreds of watersheds worldwide (e.g., see reviews by Gassman et al., 2007; 2014; Gassman and Wang, 2015; Douglas-Mankin et al., 2010; Tuppad et al., 2011; Bressiani et al., 2015; Krysanova and White, 2015).

This study builds on several previous RRW SWAT studies including three initial studies (Jha et al., 2007; Burkart and Jha, 2007; Feng et al., 2009) that were performed with SWAT version 2000 (SWAT2000), which were constructed using standard 10-digit watersheds (USGS, 2012) to delineate the subwatershed boundaries. An improved SWAT modeling system was then constructed using SWAT version 2005 (SWAT2005) that utilized an updated framework that relied on standard 12-digit watersheds (USGS, 2012; Fig. 1) as the basis for the subwatershed boundaries. This updated SWAT2005 modeling framework has been applied for scenarios performed in support of the RRW TMDL (Schilling et al., 2008b; Jha et al., 2010a; 2010b), analyses of widespread adoption of alternative perennial crops within the RRW (Schilling et al., 2008a; 2014) and was further adapted for this study. A revised set of baseline management assumptions was also incorporated in the modeling system for the Master Plan analyses that reflected improved understanding of nutrient practices in the RRW based on expert opinion and other data sources. Thus, the specific objectives of this study were to: (1) Describe the revised baseline assumptions that were required for the Master Plan scenarios, (2) provide a brief overview of updated baseline testing results that account for the revised baseline management practices, (3) describe a suite of alternative cropping system and management practice scenarios that were analyzed in support of the Master Plan and (4) present the results of simulating the suite of scenarios with SWAT for the RRW.

\section{Description of Study Region}

The Raccoon River is a major tributary of the Des Moines River that drains nearly $9,400 \mathrm{~km}^{2}$ in portions of 17 Iowa counties in west central Iowa (Fig. 1). The main tributaries of the Raccoon River system consist of the North, Middle and South Raccoon Rivers (Fig. 1), with the longest segment extending 186 miles from its origin in Buena Vista County to the confluence of the Raccoon River with the Des Moines River in the City of Des Moines. The North and Middle Raccoon Rivers flow through the recently glaciated $(<12,000$ years old) Des Moines Lobe landform region (Fig. 1), a region dominated by low relief and poor surface drainage (Prior, 1991). In contrast, the South Raccoon River drains an older ( $>500,000$ years old) Southern Iowa Drift Plain landscape region characterized by higher relief, steeply rolling hills and well-developed drainage (Fig. 1). These three main tributaries also collectively drain two 8-digit watersheds (USGS, 2012) which are typically referred to as the North Raccoon watershed and the South Raccoon Watershed (Fig. 1).

The RRW land use is dominated by agricultural row crop production, with $73.2 \%$ of the areas planted primarily to corn and soybeans (Fig. 2). Other main land use includes grassland (16.3\%), woodland (4.4\%) and urban $(4.0 \%)$. The grasses and trees generally are scattered throughout the South Raccoon basin on terrain difficult to cultivate. Fertilizer applied to cropland, primarily corn, is a key source of nitrogen and phosphorus in the RRW. The watershed is also characterized by intensive livestock production, with a total of 135 cattle feedlots and 424 confinement operations (Schilling et al., 2008a) distributed across the watershed as shown in Fig. 2. Land-applied manure generated by these livestock operations is another key source of nitrogen and phosphorus in the watershed; relatively minor nutrient inputs to the watershed occur from cattle grazing on pasture. Subsurface tile drainage is used extensively within the Des Moines Lobe landform portion of the RRW (Fig. 1) and the tile drains are a key conduit of nitrate transport to the RRW stream system. There are also 77 wastewater treatment facilities in the RRW with National Pollution Discharge Elimination System permits (Fig. 1). These facilities are the primary point sources that contribute some additional nitrate and phosphorus to the Raccoon River. 


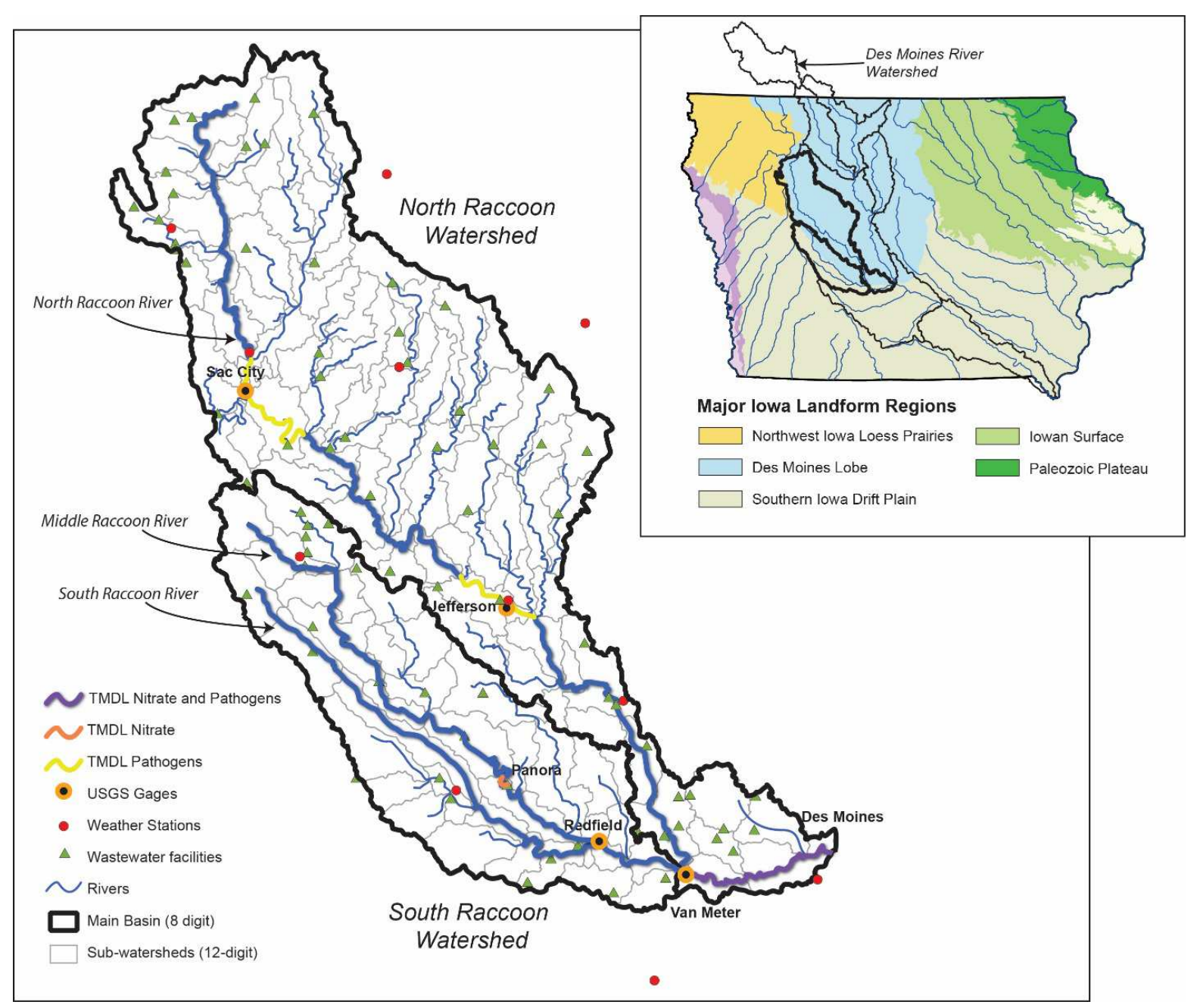

Fig. 1. Location of the Raccoon River watershed (RRW) relative to the larger Des Moines River watershed and major Iowa landform regions and location of weather stations, USGS gage sites and wastewater facilities within or near the RRW

\section{Description of SWAT}

SWAT represents over three decades of hydrological and environmental model development at the co-located U.S. Department of Agriculture and Texas A\&M University laboratories at Temple, Texas (Williams et al., 2008). The model consists of several primary and minor components including climatic inputs, hydrological (landscape water balance and watershed level routing), management practices (e.g., planting/harvesting, tillage, subsurface tile drainage, erosion control practices), crop growth and yield, sediment loss and transport, nutrient cycling and transport, pesticide fate and transport, pathogen fate and transport and the effects of reservoirs and other impoundments on flow and pollutant transport. The model is typically executed on a daily time step although sub-daily time step applications are also an option.

A watershed is simulated in SWAT by subdividing the overall watershed area into smaller subwatersheds.
Subwatersheds in a SWAT simulation are then usually further subdivided into Hydrologic Response Units (HRUs) consisting of homogeneous soils, land use and management. HRUs are not spatially represented in the model but rather represent simply the percentage of a subwatershed that contains the given HRU characteristics. A dominant HRU approach can also be used in the model in which subwatersheds are not further subdivided into the smaller HRU units; i.e., each subwatershed is effectively equivalent to single HRU representing the overall dominant soil, land use and management within the subwatershed. Surface and subsurface runoff of flow and pollutants are generated at the HRU level and then routed through downstream subwatersheds to the watershed outlet. Numerous hydrological and pollutant indicators are provided as outputs depending on the type of simulation designed by the SWAT user. 


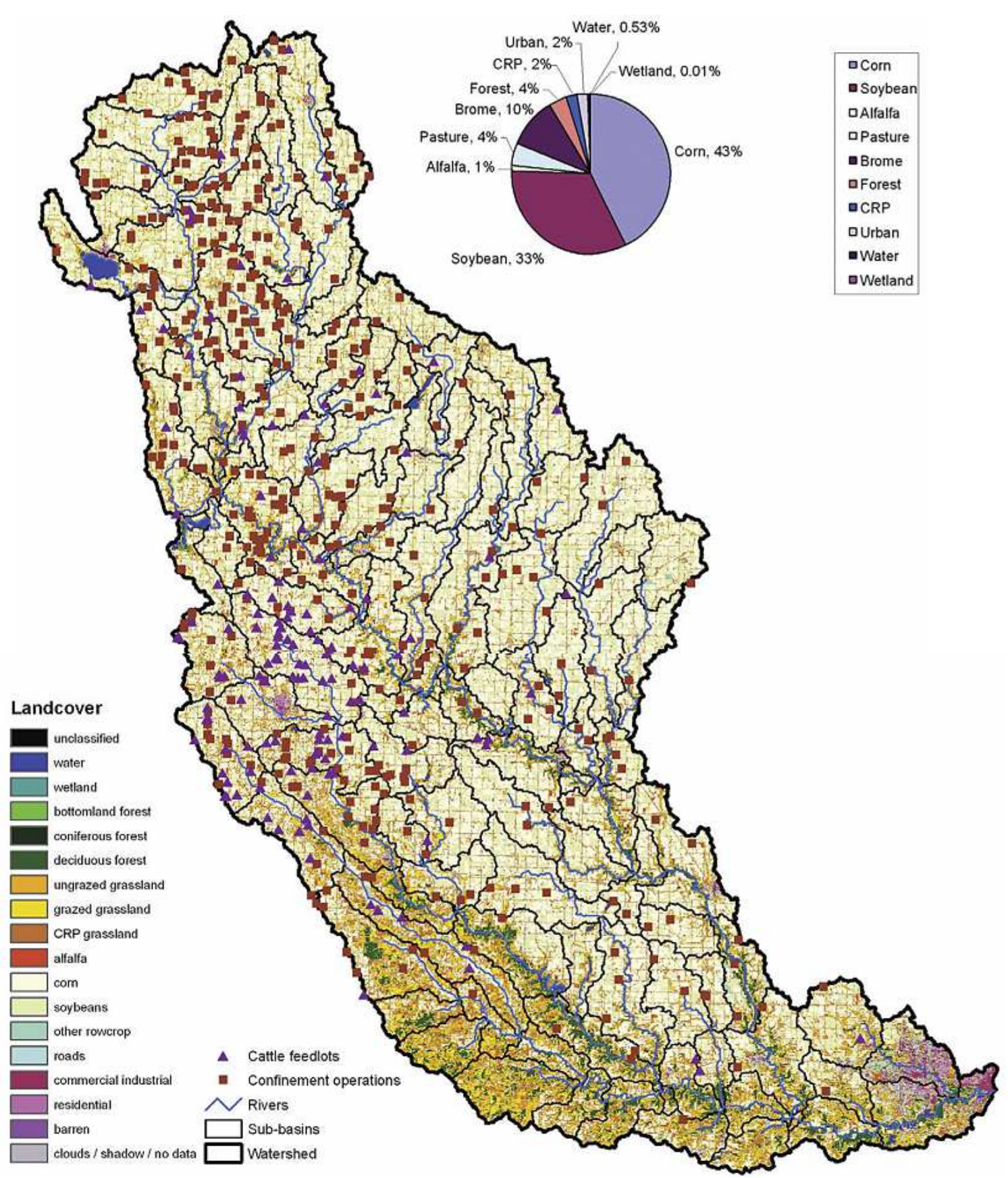

Fig. 2. Distribution of land use, cattle feedlots and other livestock confinement operations within the Raccoon River watershed

SWAT2005 was used in this study and is described in more detail in Neitsch et al. (2004; 2005) and Gassman et al. (2007).

\section{Development of SWAT Modeling System}

The key data sources used to build the SWAT modeling system for the Raccoon River watershed are listed in Table 1. The ArcView SWAT interface (AVSWATX; Di Luzio et al., 2004) was used to delineate the subwatersheds and create the HRUs as a function of a 30-meter Digital Elevation Model (DEM; USGS, 2008a), 1:100,000 scale National Hydrography Dataset (NHD; USGS, 2008b) and 12-digit watershed boundaries (USGS, 2012). The subwatersheds were delineated in a manner such that they matched the 12-digit watershed boundaries. Additional subwatersheds were also created at the gage station locations (Fig. 1) to facilitate comparisons of model output with measured data. The HRUs were then created by overlaying Soil Survey Geographic (SSURGO) data (USDA-NRCS, 2008b) and 2002 land cover data 
obtained from IDNR (2008). Thresholds of $1 \%$ for land cover and $5 \%$ for soil category were chosen so that the maximum amount of information could be captured. The resulting watershed configuration consisted of 112 subwatersheds (Fig. 1) and 3,640 HRUs.

Determination of cropland soils requiring subsurface tile drainage were based on two methods. The first method identifies soils that require subsurface tillage drainage on the basis of: Slope $<2 \%$, a drainage class of poor to very poor and a hydrologic group code of " $D$ " (D. Jaynes, Personal communication USDA National Laboratory for Soils and the Environment, Ames, Iowa). The second method used the following criteria to determine likely tile drained soils: Slope $<5 \%$, a drainage class code greater than 40 and a subsoil group of 1 or 2 (J. Miller, Personal communication, Iowa State University, Ames, Iowa). The variables for both methods are found in the Iowa Soil Properties and Interpretations Database (ISPAID) soil database (Miller et al., 2006). Soils that met either of these criteria were combined with the 2002 land cover information to identify row crop ground with probable tile drainage, resulting in an estimated 78 and $42 \%$ of the cropland in the North Raccoon and South Raccoon being tile-drained, respectively. Subsurface tile drainage was simulated in SWAT based on the methods described by $\mathrm{Du}$ et al. (2005; 2006) and Green et al. (2006) and using the parameter values listed in Table 2 . The exact impervious layer depth was not known for the RRW; it was thus set equal to the subsurface tile drain depth to reflect the fact that the subsurface drain tiles capture most of the water that leaches to that depth.

Daily precipitation and temperature data were obtained for ten locations (Fig. 1) from the National
Weather Service COOP monitoring sites available through the Iowa Environmental Mesonet (ISU, 2008). AVSWATX assigned the appropriate weather station information to each subwatershed based on the proximity of the station to the centroid of the subwatershed. The Hargreaves method was selected to estimate potential evapotranspiration and the Muskingum method was selected for channel flow routing simulation. Details of specific nutrient management related practice assumptions simulated for the Master Plan scenarios are described in the following section. Additional details regarding the development of the RRW SWAT modeling system are providing in Schilling et al. (2008a) and Jha et al. (2010a; 2010b).

\section{Fertilizer and Manure Management Assumptions}

The previous SWAT2005 simulations were performed initially in support of the watershed-level TMDL that was developed for the RRW (Schilling et al., 2008b). The assumptions incorporated into that set of simulations were based on the best available nutrient management information at that time and also reflected the fact that the simulations were performed in support of nitrate- and bacteria-related TMDLs. Several of these assumptions were modified for the RRW Master Plan simulations (Table 3) to accommodate specific scenarios, provide better overall accounting of phosphorus inputs to the stream system and/or to reflect revised convictions regarding fertilizer nutrient management in the watershed. These modifications were based in part on feedback from an expert panel that was assembled to support the development of the Master Plan.

Table 1. Digital layers and sources used to construct the Raccoon River watershed (RRW) SWAT modeling system

\begin{tabular}{lll}
\hline Data layer & Data layer description (source) & Source \\
\hline Soil & Soil Survey Geographic (SSURGO) Database & USDA-NRCS (2008b) \\
Soil & Iowa Soil Properties and Interpretations Database & Miller et al. (2006) \\
Topographic & (ISPAID) Version 7.2 & USGS (2008a) \\
Hydrologic units & National Elevation Data (NED) 30 m GRID of Iowa & USDA-NRCS (2008a) \\
Surface water & 12-digit watershed boundaries & USGS (2008b) \\
Climate data & National Hydrography Dataset (NHD) & ISU (2008) \\
Livestock operations & Iowa Environmental Mesonet, National Weather Service COOP & IDNR (2008) \\
Point sources & 2005 Confined Animal Feeding Operations (CAFOs) & IDNR (2008) \\
Land cover & Waste water treatment plants of Iowa & IDNR (2008) \\
Census data & 2002 land cover grid of Iowa & IDNR (2008) \\
Agricultural statistics & 2000 U.S. census data & USDA-NASS (2008b) \\
\hline
\end{tabular}

Table 2. Values of key input parameters used to represent subsurface tile drainage in the Raccoon River watershed (RRW) SWAT model

\begin{tabular}{llr}
\hline Input parameter & Definition & Value \\
\hline DDRAIN & Depth to the subsurface tile drain (mm) & 1200 \\
TDRAIN & Time to drain soil to field capacity (hr) & 48 \\
GDRAIN & Subsurface tile drain lag time (hr) & 96 \\
DEP_IMP & Depth to impervious layer in soil profile (mm) & 1200 \\
\hline
\end{tabular}


Table 3. Change in the calibrated baseline assumptions between the SWAT analyses performed for the Raccoon River watershed $\mathrm{TMDL}^{\mathrm{a}}$ versus the Master Plan study

\begin{tabular}{|c|c|}
\hline TMDL SWAT assumption & $\begin{array}{l}\text { Master plan SWAT assumption } \\
\text { (change from TMDL assumption) }\end{array}$ \\
\hline $\begin{array}{l}\text { No phosphorus discharge from } \\
\text { wastewater treatment facilities }\end{array}$ & $\begin{array}{l}\text { Phosphorus discharge from wastewater } \\
\text { treatment facilities accounted for }\end{array}$ \\
\hline Planting, harvesting and other field operations & Planting, harvesting and other field \\
\hline simulated using heat scheduling approach & operations simulated using specific dates \\
\hline $\begin{array}{l}\text { Cattle grazing pastures or harvested fields assumed to } \\
\text { access streams for a percentage of each day }\end{array}$ & $\begin{array}{l}\text { Cattle grazing pastures or harvested fields } \\
\text { assumed to not access streams }\end{array}$ \\
\hline $\begin{array}{l}\text { Anhydrous ammonia (nitrogen) applications } \\
\text { were always applied in the fall }\end{array}$ & $\begin{array}{l}50 \% \text { of the anhydrous ammonia (nitrogen) applications } \\
\text { applied in the fall and } 50 \% \text { applied in the spring }\end{array}$ \\
\hline $\begin{array}{l}\text { Anhydrous ammonia (nitrogen) applications were } \\
\text { simulated to occur on all cropland that was designated } \\
\text { for livestock manure applications }\end{array}$ & $\begin{array}{l}\text { The anhydrous ammonia (nitrogen) applications were } \\
\text { assumed to occur on only } 50 \% \text { of the cropland that was } \\
\text { designated for livestock manure applications }\end{array}$ \\
\hline $\begin{array}{l}\text { Anhydrous ammonia (nitrogen) was applied at } 190 \mathrm{~kg} / \mathrm{ha} \\
\text { on both cropland that was managed with manure and } \\
\text { cropland that did not receive manure }\end{array}$ & $\begin{array}{l}\text { Anhydrous ammonia (nitrogen) was applied at } 100 \mathrm{~kg} / \mathrm{ha} \\
\text { on cropland that was managed with manure and } 255 \mathrm{~kg} / \mathrm{ha} \\
\text { on cropland that did not receive manure }\end{array}$ \\
\hline
\end{tabular}

${ }^{\mathrm{a}}$ See Schilling et al. (2008b) and Jha et al. (2010a; 2010b) for more information regarding the SWAT management assumptions used for the RRW TMDL analysis

Phosphorus inputs from the wastewater facilities were previously ignored because the TMDL assessment was focused on nitrate and bacteria. However, these were included in the Master Plan baseline simulation to better account for phosphorus discharge from wastewater facilities (Table 3). An iterative process was used to calibrate the simulated phosphorus discharge from the wastewater treatment plants, which included comparisons with annual RRW phosphorus loads estimated during 2000-2002 as part of a statewide nutrient balance study that included accounting of both point and nonpoint source pollution inputs to major Iowa River watersheds (Libra et al., 2004) and additional comparisons with in-stream monitoring data during 2001-2004. Cattle (that grazed either pastures or harvested crop fields) were assumed to access the streams for a portion of each day for the TMDL SWAT baseline but were removed for the Master Plan baseline, due to the very minor effects that occurred from those direct stream nutrient inputs (see Jha et al., 2010a) and to reflect an assumed improved management of the grazed cattle. Also, as noted in Table 3, the scheduling of planting, harvesting and other field operations that were simulated in SWAT was converted from a "heat unit scheduling" approach used in the original TMDL baseline, which allows the operation dates to fluctuate as a function of temperature trends during a given growing season, to specific dates for the Master Plan simulations to facilitate scenarios that involved specific changes in fertilizer application timing.

Three key fertilizer application assumptions that were built into the baseline simulation and subsequent scenarios for that study were also adjusted for the Master Plan baseline (Table 3). First, the anhydrous ammonia applications, which were the primary simulated nitrogen fertilizer inputs for corn, were always applied in the fall for the TMDL SWAT baseline. However, these anhydrous ammonia applications were redistributed such that $50 \%$ of the primary nitrogen fertilizer applications occurred in the fall and $50 \%$ in the spring for the Master Plan baseline. Second, the anhydrous ammonia applications were also simulated to occur on all cropland that was designated for livestock manure applications in the original TMDL assumptions. This assumption was again modified, so that the anhydrous ammonia applications occurred on only $50 \%$ of the cropland that was designated for livestock manure applications. These changes reflected the overall convictions of the expert panel that the fertilizer applications are more balanced at present as compared to a few years ago for the RRW, both in terms of timing of application and that the over-utilization of nitrogen fertilizer on manured cropland was not as severe as previously believed. These assumptions were also supported by a limited amount of data available for the region, including Agricultural Coop fertilizer sales data that indicated stronger usage of anhydrous ammonia in the spring than previously observed and a small RRW subwatershed study that showed that over $40 \%$ of manured cropland also received relatively high levels of nitrogen fertilizer. Third, it was also the prevailing opinion of the expert panel that the anhydrous ammonia applications to manured cropland should be limited to $100 \mathrm{~kg} / \mathrm{ha}$ rather than the $190 \mathrm{~kg} / \mathrm{ha}$ application rate that was assumed for the TMDL baseline (Table 3 ).

The third fertilizer application rate adjustment resulted in the need to adjust the anhydrous application rates upward for nonmanured cropland in order to maintain, as close as possible, the overall nutrient balance between the TMDL and Master Plan baselines. This resulted in an increase in the anhydrous ammonia 
application rate from $190 \mathrm{~kg} / \mathrm{ha}$ in the TMDL baseline to $255 \mathrm{~kg} / \mathrm{ha}$ for the Master Plan baseline for cropland that was not managed with manure (Table 3). Achieving an exact nitrogen and phosphorus balance between the two baselines proved difficult, in spite of these adjustments, due mainly to the structure of the HRUs used in the SWAT framework. As a result, there was slightly less actual overall nitrogen and phosphorus applied across the simulated RRW in the SWAT Master Plan baseline as compared to the original TMDL baseline. In general, these modifications underscore the important need to establish the overall nitrogen and phosphorus inputs to the RRW.

\section{SWAT Calibration and Validation Methodology}

The restructured baseline was calibrated and validated using a split-time manual calibration approach that relied on the same calibration parameters and the same model testing periods previously reported by Jha et al. (2010a; 2010b). The overall simulation period was 1984 to 2004 with 1984 to 1985 serving as a two-year warm-up period. The calibration and validation time periods simulated for streamflow, sediment and nitrate were 1986 to 1995 and 1996 to 2004, respectively. Testing of in-stream SWAT estimates of organic $\mathrm{N}$, mineral $\mathrm{P}$, organic $\mathrm{P}$ and total $\mathrm{P}$ was limited to just a calibration period of 2001 to 2004, due to insufficient monitoring data for those four constituents. The simulated streamflow and pollutants were compared with corresponding measured data collected at the USGS gage located at Van Meter, Iowa (Fig. 1).

Both statistical and graphical comparisons were used to evaluate the calibrated model results versus measured data. The statistical evaluation was performed using the coefficient of determination $\left(r^{2}\right)$ and the Nash-Sutcliffe modeling Efficiency (NSE), which are described by Krause et al. (2005) and are the most common statistics used to evaluate SWAT simulations (Gassman et al., 2007; 2014; Douglas-Mankin et al., 2010; Tuppad et al., 2011). The $\mathrm{R}^{2}$ measures how well the simulated versus observed regression line approaches an ideal match and ranges from 0 to 1 , with a value of 0 indicating no correlation and a value of 1 indicating that the predicted dispersion equals the measured dispersion. The regression slope and intercept also equal 1 and 0 , respectively, for a perfect fit. The NSE values can range from $-\infty$ to 1 and indicate how accurately simulated values fit corresponding measured data on a 1:1 line. An NSE value of 1 indicates a perfect fit between the model and the measured data values. However, the mean of the measured data would be considered to be a better predictor than the model output when an $E_{N S}$ value is equal to or less than zero.
Moriasi et al. (2007) present suggested criteria for several different statistics for judging hydrologic and water quality model results including NSE values, based on a review of previous modeling studies and associated statistical results. They propose that NSE values $\geq 0.5$ are satisfactory for monthly comparisons between water quality output and corresponding measured data, with somewhat more stringent criteria used to judge annual comparisons and more relaxed criteria used for assessing daily comparisons. The same criteria were assumed for the $\mathrm{R}^{2}$ statistics for the RRW baseline, based on similar extrapolations reported by Gassman et al. (2007; 2014).

\section{Description of Master Plan Scenarios}

The calibrated SWAT model was originally used to simulate 22 different scenarios as reported in Agren (2011) and Gassman and Jha (2011). The methodology and results for 14 of those scenarios are discussed in this study (Table 4). The calibrated baseline is identified as scenario 1. The remaining scenarios reflect in part adjustments and scenario ideas provided by the Expert panel that assisted in the development of the RRW Master Plan (Agren, 2011).

Scenario 2 depicted a shift in the main phosphorus fertilizer applications for cropland from diammonium phosphate (DAP; 18-46-0) in the calibrated baseline (scenario 1) to monoammonium phosphate (MAP; 11 52-0), which reflected increasing use of the MAP material in the RRW at the time of the development of the Master Plan and a conviction on the part of the Expert panel that the trend would likely continue. The DAP application rate of $175 \mathrm{~kg} / \mathrm{ha}$ used in the calibrated baseline was also used for the MAP applications in scenario 2. The shift to MAP was then incorporated into all subsequent scenarios listed in Table 4, starting with scenario 3. Scenario 3 was intended to represent improved nutrient management of manured cropland areas by taking better account of available nutrients in the applied manure and not overapplying fertilizer, per the conviction of the Expert Panel. Scenario 3 was performed by removing both the anhydrous ammonia and MAP fertilizer inputs from the $50 \%$ of cropland that was managed with both manure and fertilizer applications in Scenarios 1 and 2. Thus, the only source of nutrients for the manured cropland in this scenario was the manure itself. Scenario 3 also served as the "scenario baseline" because all subsequent scenarios incorporated the changes introduced in scenarios 2 and 3. Thus the results for scenarios 4 to 14 (Table 4) are reported in terms of percentage changes relative to scenario 3 in the Results and Discussion section below. Additional results comparing the relative impacts of all of the original scenarios to the calibrated baseline (scenario 1) are reported in Agren (2011) and Gassman and Jha (2011). 
Table 4. Scenario numbers and descriptions

\begin{tabular}{|c|c|}
\hline ID & Scenario Description \\
\hline 1 & Calibrated baseline; all cropland is cropped with two-year rotations of corn and soybean ${ }^{\mathrm{a}}$ \\
\hline 2 & $\begin{array}{l}\text { Conversion from diammonium phosphate (DAP; } 18-46-0 \text { ) to monoammonium phosphate (MAP; } 11-52-0 \text { ); } \\
\text { effects incorporated in all remaining scenarios starting with } 3 \text {. }\end{array}$ \\
\hline 3 & $\begin{array}{l}\text { Removal of all anhydrous ammonia (main nitrogen fertilizer input) and DAP applications from cropland that } \\
\text { was also managed with livestock manure; effects incorporated in all remaining scenarios starting with } 4 \text {. }\end{array}$ \\
\hline \multicolumn{2}{|c|}{ Scenarios 4-7: The timing of the baseline fall and spring fertilizer applications are set to the same dates ${ }^{b}$} \\
\hline 4 & Both fall and spring anhydrous ammonia applications are shifted to two weeks before planting (May 1) \\
\hline 5 & Both fall and spring anhydrous ammonia applications are shifted to the day of planting (May 1) \\
\hline 6 & and spring anhydrous \\
\hline 7 & Both fall and spring anhydrous ammon \\
\hline \multicolumn{2}{|c|}{ Scenarios 8-11: Alternative cropping system scenarios ${ }^{\mathrm{c}}$} \\
\hline 8 & $25 \%$ of cropland is converted to a six-year rotation of corn-soybean-corn-alfalfa-alfalfa- \\
\hline 9 & $50 \%$ of the cropland is converted to a six-year rotation of CSCAAA \\
\hline 10 & $75 \%$ of the cropland is converted to a six-year rotation of CSCAAA \\
\hline 11 & $100 \%$ of the cropland is converted to a six-year rotation of CSCAAA \\
\hline \multicolumn{2}{|c|}{ Scenarios 12-14: Nitrogen application timing shifts and alternative cropping system combination scenarios ${ }^{\mathrm{c}}$} \\
\hline 12 & $\begin{array}{l}\text { All anhydrous applications shifted to four weeks after planting (scenario } 7 \text { ); } 25 \% \text { conversion of cropland to } \\
\text { CSCAAA (scenario 8); insertion of rye cover crop on } 25 \% \text { of the area cropped in corn and soybean }\end{array}$ \\
\hline 13 & $\begin{array}{l}\text { All anhydrous applications shifted to four weeks after planting (scenario } 7 \text { ); } 100 \% \text { conversion of cropland to } \\
\text { CSCAAA (scenario 11); insertion of rye cover crop on } 25 \% \text { of the area cropped in corn and soybean }\end{array}$ \\
\hline 14 & $\begin{array}{l}\text { All anhydrous applications shifted to four weeks after planting (scenario } 7 \text { ); } 100 \% \text { conversion of cropland to } \\
\text { CSCAAA (scenario 11) and insertion of rye cover crop on } 100 \% \text { of the area cropped in corn and soybean }{ }^{\mathrm{d}}\end{array}$ \\
\hline \multicolumn{2}{|c|}{${ }^{\mathrm{a}}$ Cropland rotations held constant for scenarios 1 to 7 ; conversions of cropland occur for scenarios 8 to 14} \\
\hline \multicolumn{2}{|c|}{$\begin{array}{l}{ }^{\mathrm{b}} \text { The } 50 \% \text { of the simulated anhydrous applications that were applied in the spring for the calibrated baseline (and scenarios } 2 \text { and } 3 \text { ) } \\
\text { were applied on May } 2 \text {, the day before planting. However, the original spring applications were shifted to the same spring } \\
\text { application dates as the fall applications for scenarios } 4 \text { to } 7 \text {. }\end{array}$} \\
\hline \multicolumn{2}{|c|}{$\begin{array}{l}\text { 'Selection of cropland HRUs to be converted to CSCAAA rotation or for insertion of rye winter cover crop was based on a } \% \text { slope } \\
\text { targeting scheme that targeted the highest slopes first and then targeted progressively lower slopes. The initial targeting for scenario } \\
12 \text { was for the CSCAAA rotation followed by the cover crops. }\end{array}$} \\
\hline & nserted between every sequence of corn-soybean and soybean-corn that was simulated during the 25 -ye \\
\hline
\end{tabular}

The remaining 11 scenarios are grouped according to three main categories in Table 4. Scenarios 4-7 represent adaptive nutrient management scenarios in which the $50 \%$ of the anhydrous ammonia applications that were applied in the fall (as simulated in scenarios 1 to 3 ) were shifted to spring applications (Table 4). The fall applications were shifted to four specific dates relative to the assumed May 1 planting date for corn: Two weeks before planting (scenario 4), the day of planting (scenario 5), two weeks after planting (scenarios 6) and four weeks after planting (scenario 7).

In scenarios 8 to 11 , the standard RRW corn-soybean cropping systems were progressively converted to a sixyear rotation of Corn-Soybean-Corn-Alfalfa-AlfalfaAlfalfa (CSCAAA), starting with a $25 \%$ conversion of the overall RRW cropland in scenario 8 and ending with a $100 \%$ conversion in scenario 11 (Table 4). The selection of which cropland HRUs to be converted to the CSCAAA rotation was based on a percent slope targeting scheme that targeted the highest cropland slopes first and then targeted progressively lower slopes, ultimately resulting in all landscapes being converted to the CSCAAA rotation in scenario 11 .
Scenarios 12 through 14 incorporate various combinations of the adaptive nutrient management and alternative cropping systems (Table 4). The adaptive nutrient management in these three scenarios was represented by shifting all of the anhydrous applications to four weeks after planting (scenario 7). The alternative cropping systems included conversion to the CSCAAA rotation and the insertion of a rye cover crop on portions of the row cropped areas. Conversions of $25 \%$ of the row cropped area were simulated in scenario 12, for conversion to both CSCAAA and the insertion of a rye cover crop between corn and soybean production cycles. The percent slope targeting was applied first to the $25 \%$ conversion to CSCAAA was based on the highest slopes followed by the next highest $25 \%$ sloped cropland for the targeted adoption of over crops. Scenario 13 was primarily an interface of scenarios 7 and 11 , with $100 \%$ conversion of cropland to the CSCAAA rotation; insertion of the rye cover crop also occurred on $25 \%$ of the area cropped to corn or soybean within the six-year CSCAAA rotation. Scenario 14 was a variant of scenario 13 , in which adoption of cover crops was depicted for both winter periods during the CSC sequence of the six-year rotation. 


\section{Results and Discussion}

\section{SWAT Model Calibration and Validation (Scenario 1)}

The statistical results computed for the baseline (scenario 1; Table 4) streamflow, sediment and nitrate calibration and validation periods are reported in Table 5 . Corresponding aggregated annual and monthly graphical comparisons with measured in-stream streamflow, sediment or nitrate data are shown in Fig. 4 to 9.

The plots of annual and monthly predicted streamflows in Fig. 4 and 5 accurately replicated the corresponding measured trends in both figures. There was a slight over-prediction of average annual streamflow as shown in Fig. 4, reflecting over-predictions of streamflow that occurred in some years including 1986, 1991 and 2001 through 2004. Peak monthly flows were also overpredicted in most of those same years while underprediction of peak monthly flows occurred in 1990 and 1993. The computed $r^{2}$ and NSE annual or monthly statistics (Table 5) further confirm the accuracy of the simulated streamflows, which ranged between 0.84 to 0.97 for the calibration period and 0.68 to 0.86 for the validation period and clearly exceeded the NSE criteria of 0.5 suggested by Moriasi et al. (2007).

Sediment yields were accurately simulated in most years and months (Fig. 6 and 7) and the long-term annual average simulated sediment yield was nearly identical to the measured counterpart (Fig. 6). However, considerable inaccuracy in the predicted sediment yields occurred in some years including large under-predictions in 1986 and 1998 versus a large over-prediction in 2011 (Fig. 6). These mismatches between the predicted and measured sediment yields were also reflected for those years in the estimates of the monthly sediment peaks (Fig. 7). The statistical results (Table 5) were generally strong for the computed annual and monthly $\mathrm{r}^{2}$ and NSE sediment yield statistics, although the annual $\mathrm{r}^{2}$ and NSE calibration statistics of 0.45 and 0.44 indicate that SWAT was not able to replicate the measured trends as accurately for the 1986 to 1995 time period.

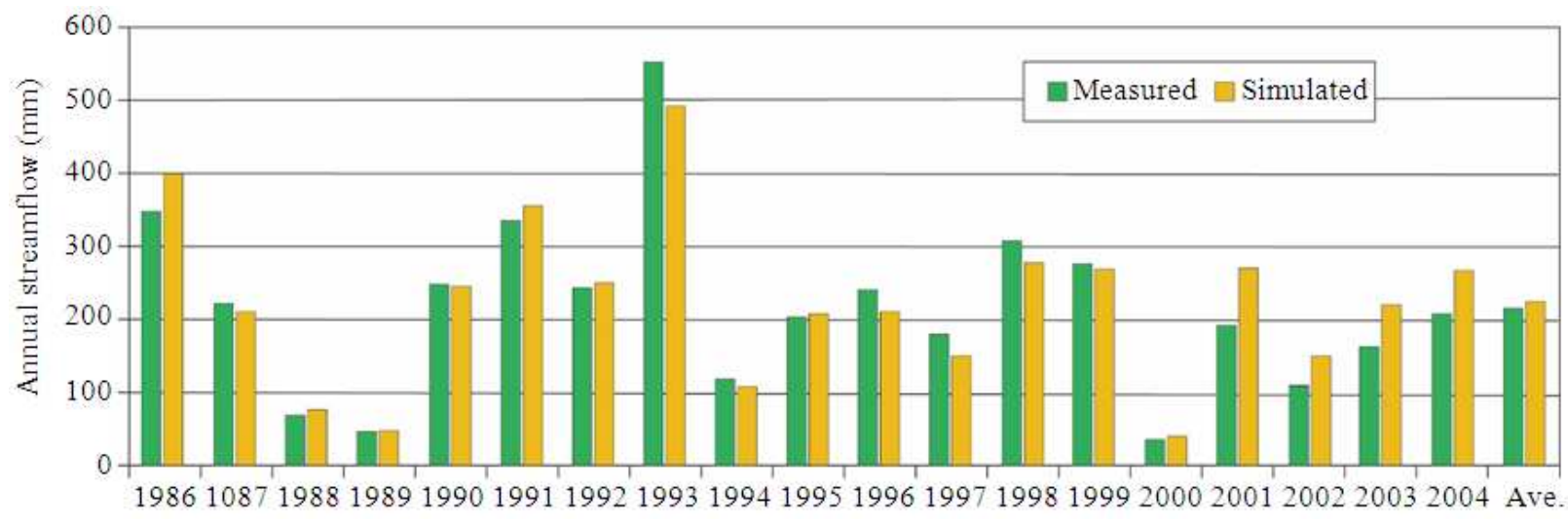

Fig. 4. Comparisons of annual simulated and measured Raccoon River Watershed (RRW) streamflows at Van Meter (Fig. 1)

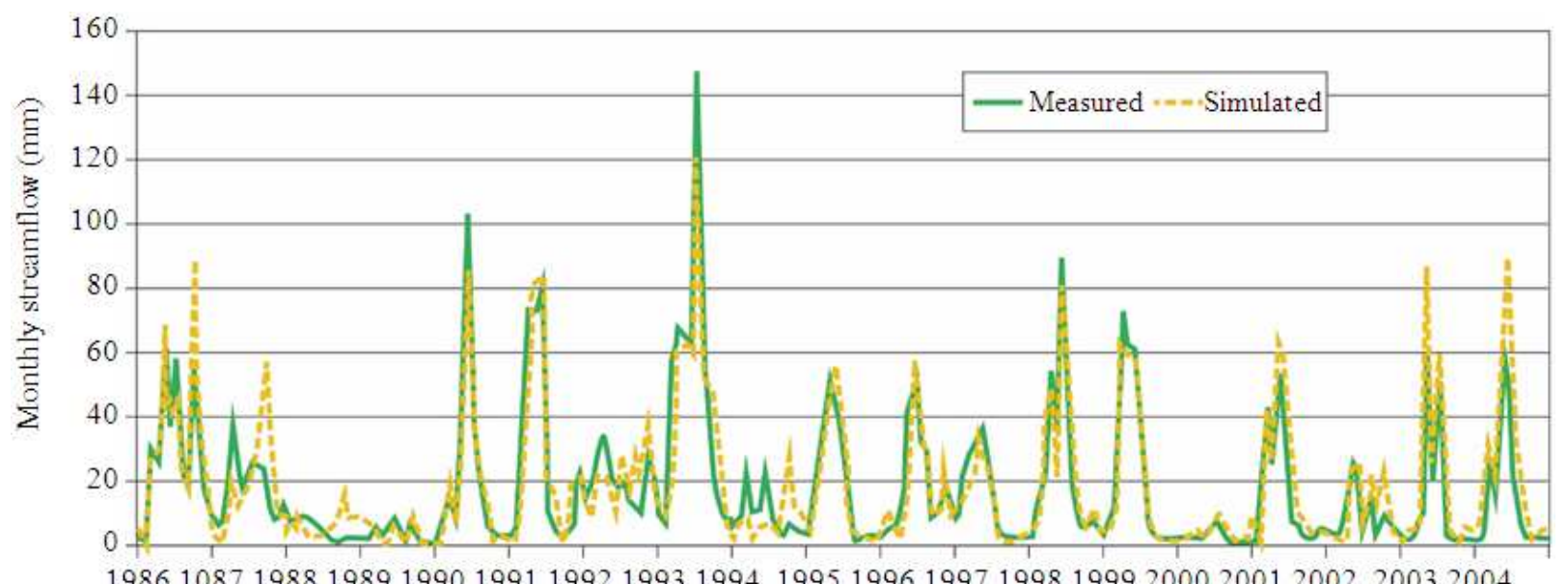

Fig. 5. Comparisons of monthly simulated and measured Raccoon River Watershed (RRW) streamflows at Van Meter (Fig. 1) 


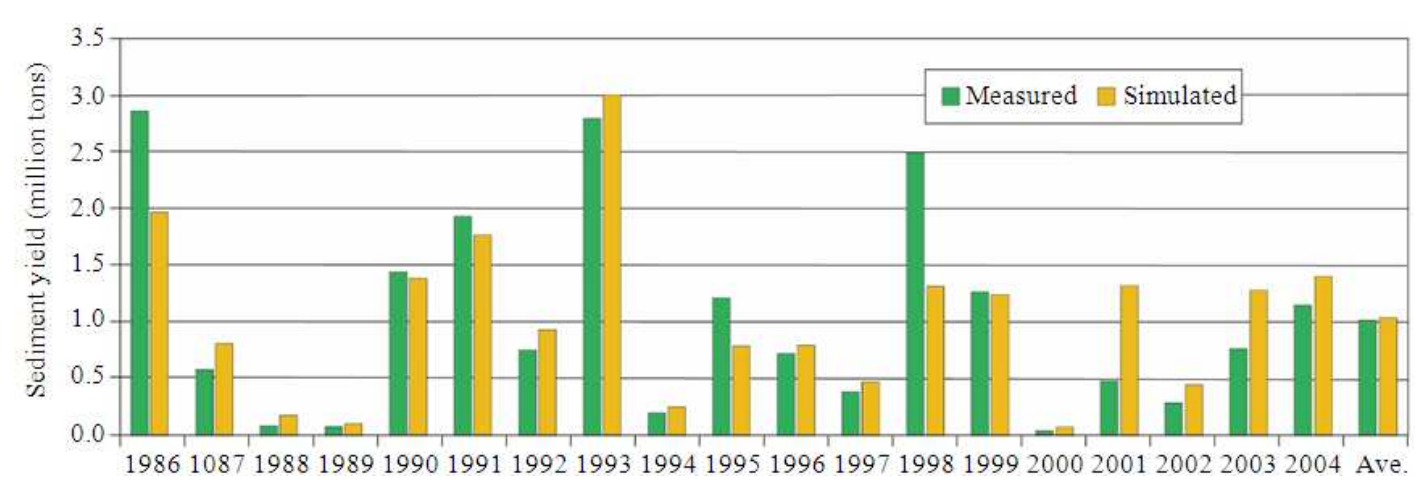

Fig. 6. Comparisons of annual simulated and measured Raccoon River Watershed (RRW) sediment loads at Van Meter (Fig. 1)

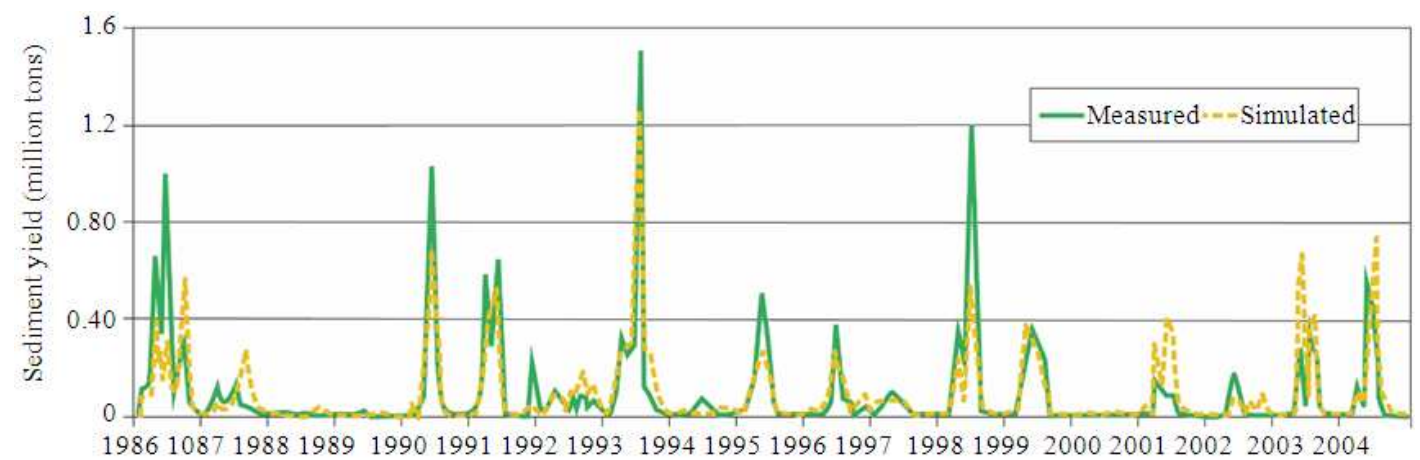

Fig. 7. Comparisons of monthly simulated and measured Raccoon River Watershed (RRW) sediment loads at Van Meter (Fig. 1)

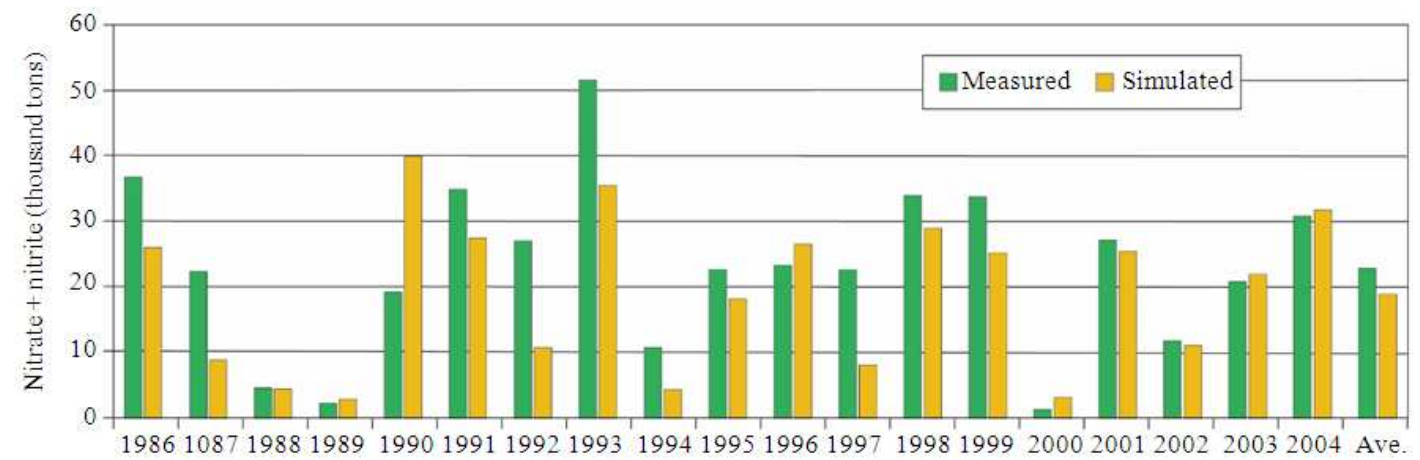

Fig. 8. Comparisons of annual simulated and measured Raccoon River Watershed (RRW) nitrate loads at Van Meter (Fig. 1)

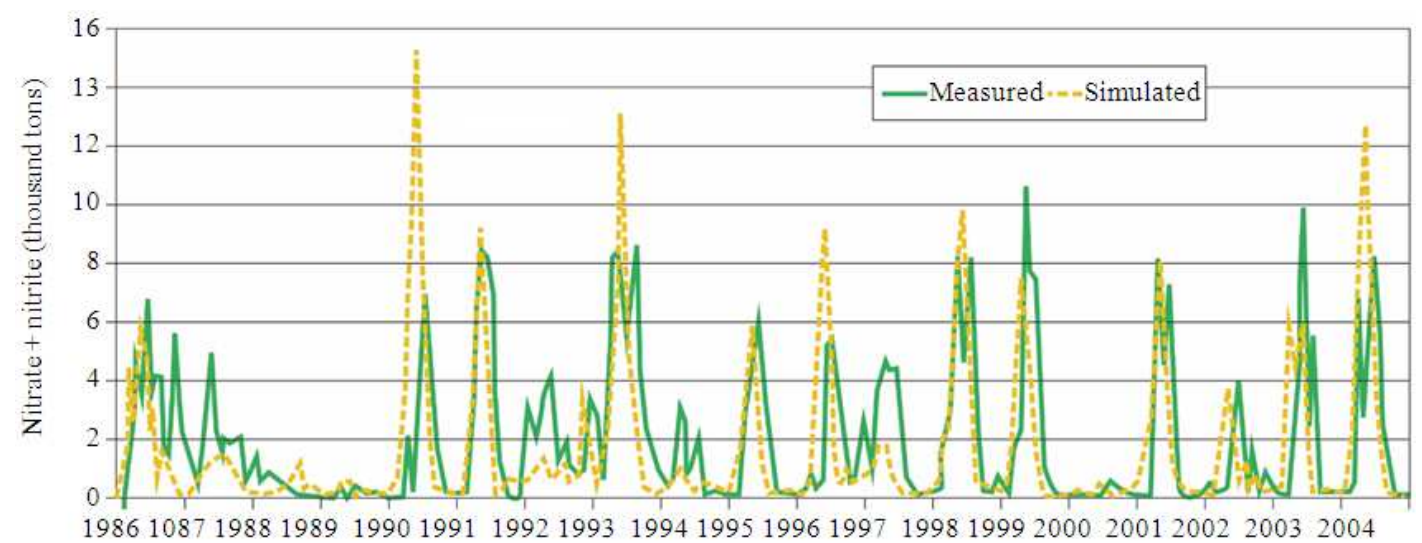

Fig. 9. Comparisons of monthly simulated and measured Raccoon River Watershed (RRW) nitrate loads at Van Meter (Fig. 1) 
Table 5. Calibration and/or validation for SWAT streamflow and nutrient predictions near the watershed outlet of the Raccoon River watershed

\begin{tabular}{|c|c|c|c|c|c|c|}
\hline \multirow[b]{2}{*}{ Indicator } & \multirow{2}{*}{$\begin{array}{l}\text { Calibration } \\
\text { or validation }\end{array}$} & \multirow[b]{2}{*}{ Time period } & \multicolumn{2}{|c|}{ Annual } & \multicolumn{2}{|c|}{ Monthly } \\
\hline & & & $r^{2}$ & E & $r^{2}$ & $\mathrm{E}$ \\
\hline \multirow[t]{2}{*}{ Streamflow } & Calibration & 1986-1995 & 0.97 & 0.97 & 0.84 & 0.84 \\
\hline & Validation & $1996-2004$ & 0.74 & 0.68 & 0.86 & 0.83 \\
\hline \multirow[t]{2}{*}{ Sediment } & Calibration & 1986-1995 & 0.90 & 0.89 & 0.79 & 0.78 \\
\hline & Validation & $1996-2004$ & 0.45 & 0.44 & 0.57 & 0.56 \\
\hline \multirow[t]{2}{*}{ Nitrate $\left(\mathrm{NO}_{3}\right)$} & Calibration & 1986-1995 & 0.72 & 0.35 & 0.58 & 0.26 \\
\hline & Validation & 1996-2004 & 0.80 & 0.64 & 0.76 & 0.53 \\
\hline Organic N & Calibration & 2001-2004 & 0.47 & 0.15 & 0.62 & 0.56 \\
\hline Mineral P & Calibration & 2001-2004 & 0.60 & 0.13 & 0.63 & 0.55 \\
\hline Organic $\mathrm{P}$ & Calibration & 2001-2004 & 0.28 & 0.17 & 0.60 & 0.57 \\
\hline Total P & Calibration & $2001-2004$ & 0.90 & 0.73 & 0.85 & 0.82 \\
\hline
\end{tabular}

The measured nitrate loads were under-predicted by SWAT in several years (e.g., 1986, 1993, 1997 and 1998) and also on an average annual basis (Fig. 8). The model generally replicated the monthly trends well (Fig. 9) although over- or under-predictions of the measured peaks are evident in several years. The overall under-prediction of the nitrate loads were partially due as a result of the lower overall nitrate inputs simulated for the Master Plan simulations as compared to the previous TMDL assessment, pointing to the need to determine the most accurate nutrient balance possible for the RRW. The majority of computed nitrate-related statistics ranged from just above 0.50 To 0.80 (Table 5), indicating satisfactory to strong replication of the measured nitrate loads. However, weaker NSE statistics of 0.35 and 0.26 resulted for the calibration annual and monthly nitrate load predictions, revealing that SWAT again did not track the measured loads as accurately during the 1986 to 1995 calibration period.

Several of the calculated annual organic N, mineral $\mathrm{P}$ and organic $\mathrm{P} \mathrm{r}^{2}$ and NSE values were obviously quite weak (Table 5). However, these weaker statistics were influenced by the limited number of data points available over four years for comparison. In contrast, the monthly statistical values (Table 5) all exceeded 0.5 and the graphical results for each indicator also indicate that the simulated values captured much of the measured trends and variability as reported in Agren (2011) and Gassman and Jha (2011).

The resulting calibrated baseline 12-digit subwatershed-level water yields or pollutant loads are shown in Fig. 10a to d. Figure 10a shows the predicted distribution of water yields across the RRW, which reflect the effects of varying land use, topography and soil types. Figure $10 \mathrm{~b}$ indicates that the highest baseline sediment losses occurred primarily in the South Raccoon subwatershed, reflecting the more rolling landscapes and steeper slopes that characterize that area as compared to the rest of the RRW. Figure 10c presents a similar pattern for total phosphorus losses as compared to the sediment losses in Fig. 10b, which is consistent with expectations due to higher surface runoff and sediment losses that occurred from the higher sloped landscapes in the South Raccoon subwatershed (e.g., see Randall et al. (2002) and Sharpley et al. (2002) for further discussion regarding phosphorus transport on eroded sediment). In contrast, the highest nitrate losses were predicted to occur in the northern and central parts of the RRW (Fig. 10d), which is coincident with the highest concentration of swine operations and areas of the watershed with high levels of subsurface tile drainage.

The relative magnitudes of the per hectare total $\mathrm{P}$ and nitrate losses between the South Raccoon and North Raccoon subwatersheds (Fig. 10c and d) is consistent with 14-year (2000 to 2013) average annual total $\mathrm{P}$ and nitrate losses (Table 6) measured at Sac City, the outlet of the South Raccoon subwatershed and the overall RRW outlet (Fig. 1). The measured loads show that the highest total $\mathrm{P}$ loads are discharged from the South Raccoon subwatershed versus the North Raccoon being the source of the highest total nitrate loads, which confirms the spatial patterns predicted by SWAT. The overall per hectare total P losses predicted by SWAT are somewhat higher for the South Raccoon subwatershed compared to the long-term annual average measured during 2000 to 2013 and the opposite relationship holds for the per hectare nitrate losses for the North Raccoon subwatershed and the overall RRW. These differences are due partially to the different time period simulated in SWAT as compared to the time period the measured loads are based on. In addition, there is likely some under-estimate of the total nitrate inputs to the RRW system in this study as previously noted which in turn results in lower spatial estimates of nitrate at the 12-digit watershed level. 


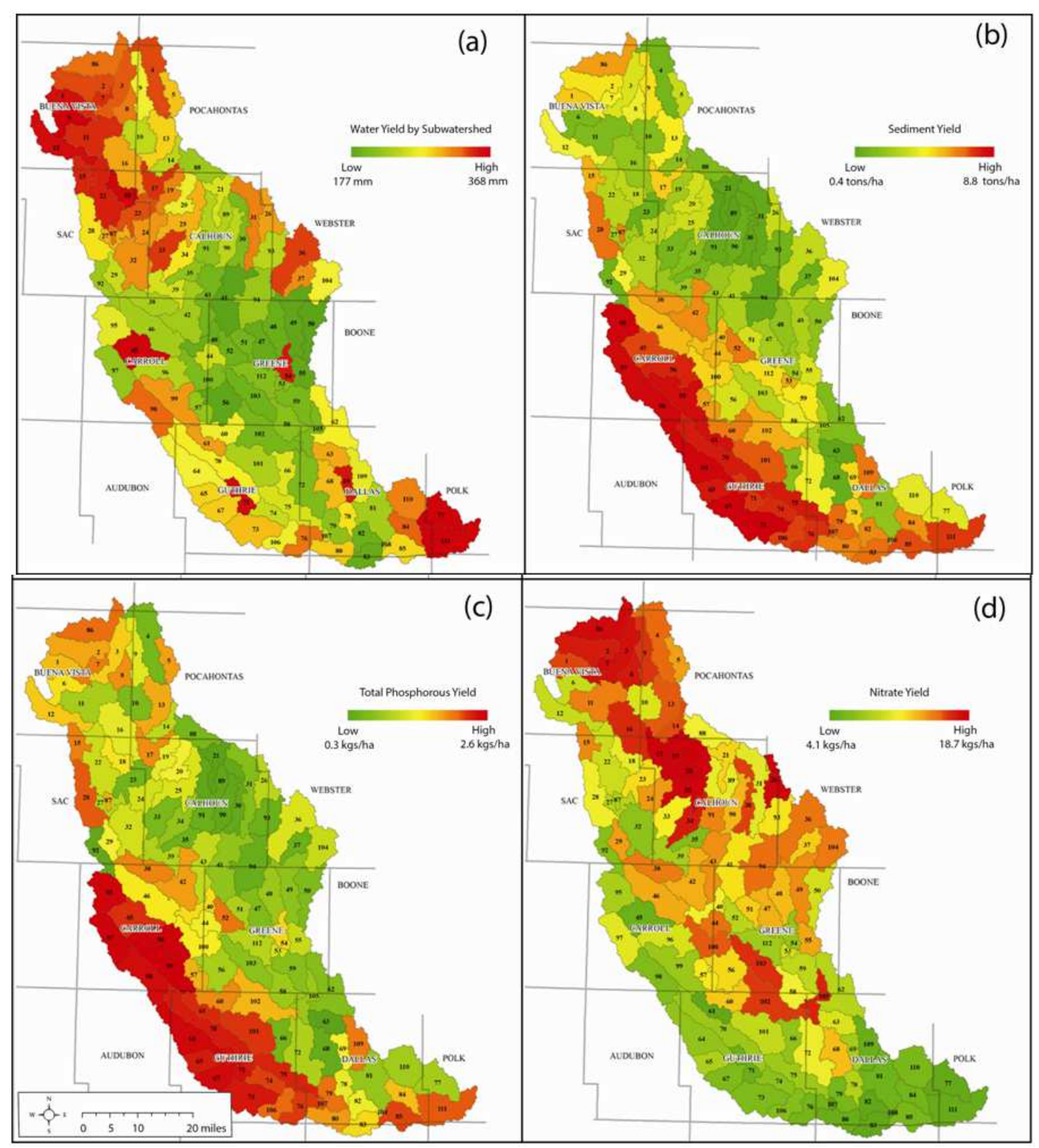

Fig. 10. Spatial distribution of simulated long-term (1986-2004) calibrated baseline (Scenario 1) indicators: (a) Water yield mm) (b) sediment yield (t/ha) (c) total phosphorus yield ( $\mathrm{kg} / \mathrm{ha})$ and $(\mathrm{d})$ nitrate yield $(\mathrm{kg} / \mathrm{ha})$

Table 6. Average annual total P and nitrate loads $(\mathrm{kg} / \mathrm{ha})$ measured at Sac City, the outlet of the South Raccoon subwatershed and the overall RRW outlet ${ }^{\mathrm{a}}$ during the 14-year period of 2000 to 2013

\begin{tabular}{lccr}
\hline Nutrient indicator & Sac city & South raccoon outlet & RRW outlet \\
\hline Total P & 0.76 & 1.55 & 1.01 \\
Nitrate & 22.30 & 14.50 & 18.40 \\
\hline
\end{tabular}

${ }^{\mathrm{a}}$ Locations shown in Figure 1

\section{Scenarios 2 and 3}

The results of scenarios 2 and 3 (Table 4) are presented in Table 7. For scenario 2, a decrease of close to $3 \%$ was predicted for the nitrate loss versus slight increases of about 1 to $3 \%$ in the estimated organic $\mathrm{P}$ and mineral P losses. These impacts are consistent with the formulation differences between DAP and MAP (Table 1) and indicate that only minor environmental impacts would occur with widespread conversion to MAP. 
Reductions in nitrate and mineral P losses of over $10 \%$ were predicted for scenario 3 versus the calibrated baseline, in response to the removal of fertilizer applications to the manured cropland areas. Slight increases in streamflow and sediment loss were also predicted for scenario 3 , due to a small decrease in the average corn yields of $3.5 \%$ (because of the fertilizer reductions) and associated biomass which in turn resulted in increased surface runoff and sediment loss. Organic $\mathrm{P}$ was predicted to decrease by $1.5 \%$, reflecting the counteracting effects of the reduced fertilizer applications versus the increased sediment loss; i.e., the effect of the reduced fertilizer applications was greater than the effect of the increased sediment loss. The spatial patterns of water yield and per hectare sediment, total $\mathrm{P}$ and nitrate losses that resulted at the 12-digit subwatershed level (reported in Agren, 2011; Gassman and Jha, 2011) were similar to those shown in Fig. 10a-d but reflect the impact of the lower nutrient application rates incorporated in Scenario 3.

\section{Scenarios 4 to 7}

The results of the four adaptive nutrient management scenarios (scenarios 4 to 7; Table 4) are shown in Table 8 versus the scenario baseline (scenario 3). The main effect of these scenarios was decreased losses in nitrate relative to scenario 3 , as was expected. The magnitude of the predicted decrease in nitrate loss increased as the applications were shifted further into the corn growing season, indicating that applied nitrogen was more efficiently used by the corn plants and less was available for being lost to the stream system. The largest predicted decrease of slightly over $12 \%$ occurred for scenario 7 when $100 \%$ of the anhydrous ammonia was applied four weeks after planting. The average corn yields predicted for these scenarios were slightly higher than those predicted for scenario 3, which was a further confirmation that the applied nitrogen was utilized better by the corn plants. This in turn resulted in small decreases in streamflow (runoff), sediment loss and organic $\mathrm{N}$ and $\mathrm{P}$ losses.

Percentage changes that occurred in streamflow, sediment, phosphorus and nitrate yields between scenario 7 and the scenario baseline (scenario 3) are represented spatially across the RRW 12-digit subwatersheds in Fig. 11a-d. Small percentage decreases were predicted for streamflow (Fig. 11a), sediment (Fig. 11b) and phosphorus (Fig. 11c), which again resulted from the increased corn biomass. The spatial changes for nitrate (Fig. 11d) were much more dramatic and decreased by as much as $35 \%$ relative to the scenario baseline (scenario 3). In general, the greatest reductions occurred for the row-cropped tile-drained areas of the North Raccoon, especially in areas that had lower densities of swine operations and thus less manure applied to cropland (Fig. 2).

\section{Scenarios 8 to 11}

The results of scenarios 8 to 11 (Table 4), as compared with scenario 3 (Table 9), show that large reductions in streamflow and pollutant losses were predicted to occur with increasing adoption of the sixyear CSCAAA rotation. Reductions in streamflow ranged from 7 to $26 \%$ across the four scenarios, reflecting higher levels of predicted evapotranspiration in response to the increased levels of perennial alfalfa forage crops. Sediment loss reductions ranged from $13 \%$ to over $38 \%$; the associated organic $\mathrm{N}$ and $\mathrm{P}$ losses being were even higher, exceeding over 56 and $57 \%$, respectively for $100 \%$ conversion to CSCAAA. The impacts on nitrate losses were somewhat lower, reaching a maximum reduction of $31 \%$ for the $100 \%$ conversion to CSCAAA scenario. In general, the impacts of the CSCAAA adoption scenarios on reducing cropland pollutant losses confirm the potential effectiveness of more widescale adoption of perennial grasses within typical row crop production systems.

Table 7. Percentage differences between the calibrated baseline (scenario 1) and the average annual (1986-2004) streamflows or pollutant losses for scenarios 2 and 3

\begin{tabular}{lllllll}
\hline Scenario & $\begin{array}{l}\text { Streamflow } \\
(\mathrm{mm})\end{array}$ & $\begin{array}{l}\text { Sediment } \\
\text { (Tons) }\end{array}$ & $\begin{array}{l}\text { Nitrate } \\
\text { (Tons) }\end{array}$ & $\begin{array}{l}\text { Organic } \\
\text { N (Tons) }\end{array}$ & $\begin{array}{l}\text { Mineral } \\
\text { P (Tons) }\end{array}$ & $\begin{array}{l}\text { Organic } \\
\text { P (Tons) }\end{array}$ \\
\hline 1 & 224 & $1,022,934$ & 19,266 & 2,879 & 490 & 427 \\
2 & -0.1 & -0.1 & -2.7 & 0.0 & 3.2 & 0.9 \\
3 & 1.2 & 1.7 & -10.5 & 0.0 & -11.2 & -1.5 \\
\hline
\end{tabular}

Table 8. Percentage differences between the scenario baseline (scenario 3) and the average annual (1986-2004) streamflows or pollutant losses for scenarios 4 through 7

\begin{tabular}{lllllll}
\hline Scenario & $\begin{array}{l}\text { Streamflow } \\
(\mathrm{mm})\end{array}$ & $\begin{array}{l}\text { Sediment } \\
(\text { Tons })\end{array}$ & $\begin{array}{l}\text { Nitrate } \\
(\text { Tons })\end{array}$ & $\begin{array}{l}\text { Organic } \\
\text { N (Tons) }\end{array}$ & $\begin{array}{l}\text { Mineral } \\
\text { P (Tons) }\end{array}$ & $\begin{array}{l}\text { Organic } \\
\text { P (Tons) }\end{array}$ \\
\hline 3 & 227 & $1,040,455$ & 17,242 & 2,879 & 435 & 421 \\
4 & 0.0 & 0.0 & -1.3 & 0.1 & 0.0 & 0.0 \\
5 & -0.2 & -0.2 & -3.2 & 0.0 & 0.1 & -0.2 \\
6 & -0.5 & -0.7 & -7.5 & -0.1 & 0.1 & -0.6 \\
7 & -0.8 & -1.2 & -12.3 & -0.3 & 0.1 & -1.1 \\
\hline
\end{tabular}


Table 9. Percentage differences between the scenario baseline (scenario 3) and the average annual (1986-2004) streamflows or pollutant losses for scenarios 8 to 11

\begin{tabular}{lllllll}
\hline Scenario & $\begin{array}{l}\text { Streamflow } \\
(\mathrm{mm})\end{array}$ & $\begin{array}{l}\text { Sediment } \\
(\text { Tons }\end{array}$ & $\begin{array}{l}\text { Nitrate } \\
(\text { Tons) }\end{array}$ & $\begin{array}{l}\text { Organic } \\
\text { N (Tons) }\end{array}$ & $\begin{array}{l}\text { Mineral } \\
\text { P (Tons) }\end{array}$ & $\begin{array}{l}\text { Organic } \\
\text { P (Tons) }\end{array}$ \\
\hline 3 & 227 & $1,040,455$ & 17,242 & 2,879 & 435 & 421 \\
8 & -7.0 & -13.3 & -9.1 & -34.2 & -14.7 & -37.1 \\
9 & -13.2 & -22.1 & -17.4 & -45.1 & -20.9 & -47.6 \\
10 & -19.7 & -30.7 & -22.9 & -50.2 & -26.2 & -53.1 \\
11 & -26.2 & -38.4 & -31.1 & -54.6 & -31.3 & -57.4 \\
\hline
\end{tabular}

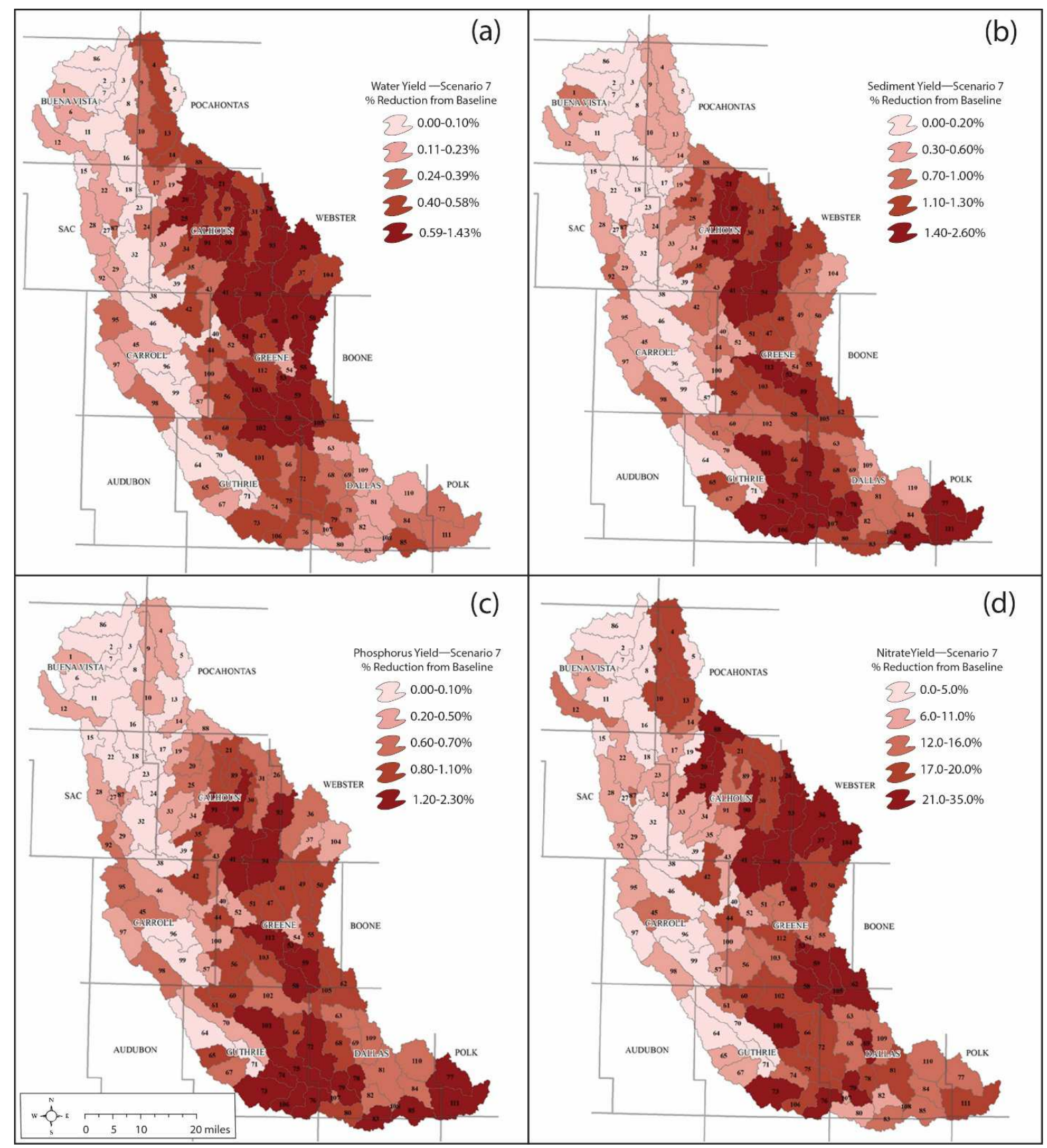

Fig. 11. Spatial distribution of simulated long-term (1986-2004) scenario 7 (Table 2) indicators: (a) Water yield (mm) (b) sediment yield (t/ha) (c) total phosphorus yield $(\mathrm{kg} / \mathrm{ha})$ and $(\mathrm{d})$ nitrate yield $(\mathrm{kg} / \mathrm{ha})$ 


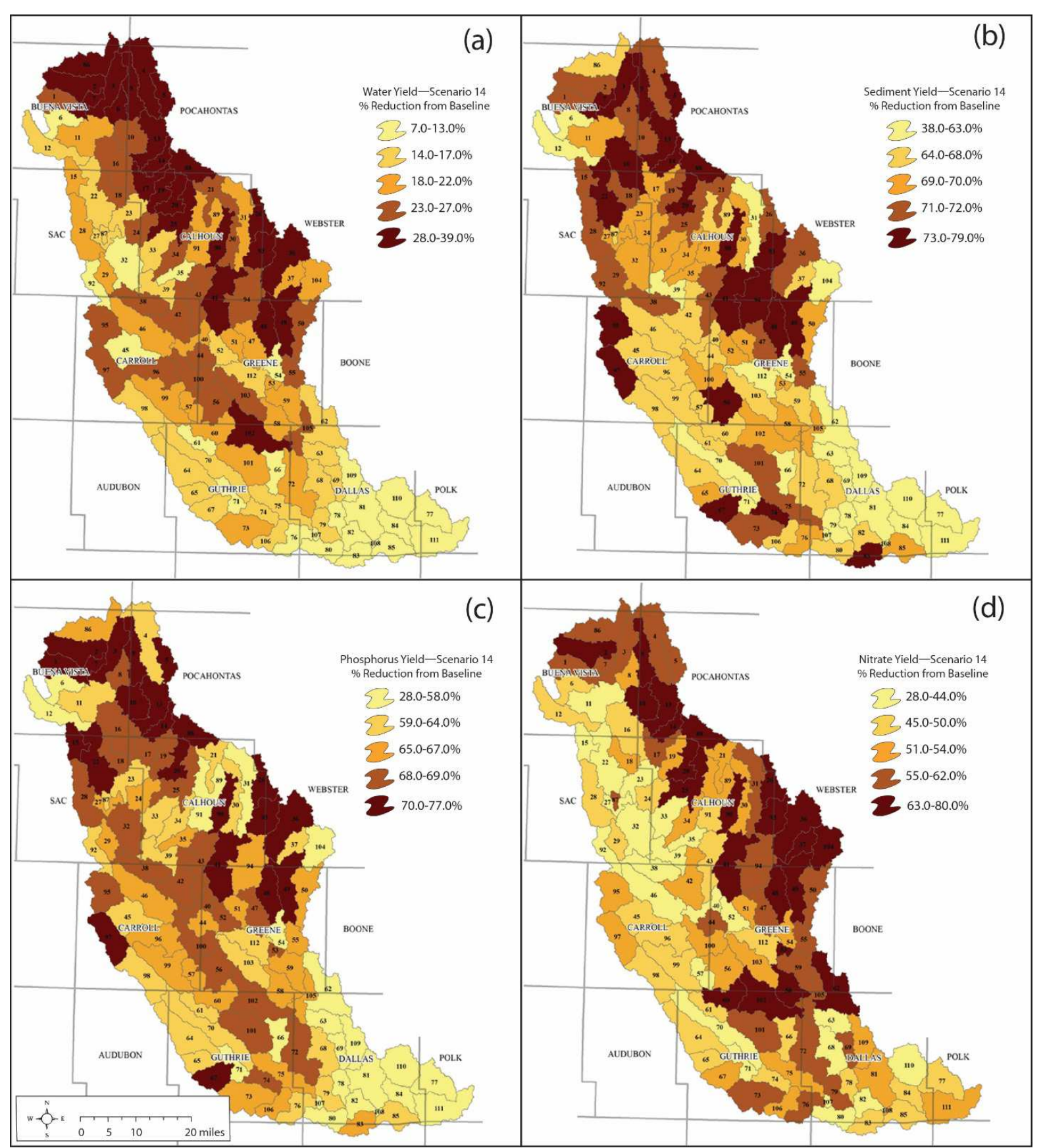

Fig. 12. Spatial distribution of simulated long-term (1986-2004) scenario 14 (Table 2) indicators: (a) water yield (mm) (b) sediment yield (t/ha) (c) total phosphorus yield ( $\mathrm{kg} / \mathrm{ha})$ and $(\mathrm{d})$ nitrate yield $(\mathrm{kg} / \mathrm{ha})$

Table 10. Percentage differences between the scenario baseline (scenario 3) and the average annual (1986-2004) streamflows or pollutant losses for scenarios 12 to 14

\begin{tabular}{lllllll}
\hline Scenario & $\begin{array}{l}\text { Streamflow } \\
(\mathrm{mm})\end{array}$ & $\begin{array}{l}\text { Sediment } \\
\text { (Tons) }\end{array}$ & $\begin{array}{l}\text { Nitrate } \\
\text { (Tons) }\end{array}$ & $\begin{array}{l}\text { Organic } \\
\text { N (Tons) }\end{array}$ & $\begin{array}{l}\text { Mineral } \\
\text { P (Tons) }\end{array}$ & $\begin{array}{l}\text { Organic } \\
\text { P (Tons) }\end{array}$ \\
\hline 3 & 227 & $1,040,455$ & 17,242 & 2,879 & 435 & 421 \\
12 & -19.2 & -30.0 & -27.0 & -56.6 & -32.9 & -60.1 \\
13 & -26.5 & -38.7 & -43.1 & -54.5 & -31.2 & -57.5 \\
14 & -29.0 & -42.2 & -50.1 & -64.5 & -34.4 & -66.6 \\
\hline
\end{tabular}




\section{Scenarios 12 to 14}

The results of scenarios 12 to 14 (Table 4) are shown in Table 10, again on the basis of percentage reductions relative to the scenario baseline (scenario 3). The overall greatest impacts were predicted for these three scenarios, with pollutant reductions ranging from $27 \%$ to almost $67 \%$. The nitrate reduction of $50 \%$ for scenario 14 meets the previously described TMDL goal of $48 \%$ and both scenarios 13 and 14 meet this nitrate goal when compared against the calibrated baseline (Agren, 2011; Gassman and Jha, 2011). It is further likely that the full effects of scenarios 12 to 14 were somewhat underpredicted due to apparent weaknesses in SWAT2005 to replicate the biomass levels expected for rye cover crops in the RRW region (as discussed further in Agren (2011) and Gassman and Jha (2011). Overall, these combination runs underscore the need to look at more complex scenarios that represent the cumulative impact of different management and cropping practices in the RRW and similar watershed systems, rather than focusing on just the impacts of single practices for all of the simulation scenarios.

Example spatial results by subwatershed are shown in Fig. 12a-d for the percentage differences in the water, sediment, total phosphorus and nitrate yields between scenarios 14 and 3 (scenario baseline). Substantial percentage decreases were predicted for all four indicators but with some variation in the distribution of the greatest impacts. Most of the largest percentage decreases were estimated to occur in subwatersheds concentrated in the northeastern portion of the North Raccoon subregion, which as noted above is a heavily row-cropped and tile-drained subregion. However, some larger percentage decreases were predicted to occur in a subset of South Raccoon subwatersheds for the sediment and phosphorus losses. In contrast, higher percentage decreases for the water and nitrate yields extended more into the central RRW (mainly in the North Raccoon subregion). The pattern of nitrate decreases predicted for scenario 14 were generally similar to those predicted for scenario 7 (Fig. 11d), although distinct differences can be seen such as a much greater relative impact in the far northern subwatersheds for scenario 14. High percentage decreases clearly do not translate to high decreases in the magnitude of a given pollutant; e.g., the estimated magnitudes of sediment yield decreases for subwatersheds 64 and 65 are roughly 5 times greater than the magnitude of soil loss decrease predicted for subwatershed 3 and 5 .

\section{Conclusion}

The SWAT modeling system adapted from the previous RRW TMDL assessment proved generally robust for capturing many of the scenarios for the RRW
Master Plan simulation study. The modeling results demonstrated that a mix of nutrient management and alternative cropping systems were needed to obtain the most substantial reductions in pollutant loss. The results also show that meeting the TMDL goal of a $48 \%$ reduction in nitrate requires adopting relatively extreme shifts in nutrient management and cropping systems which are not realistic considering current agricultural sector commodity needs, market influences and government incentives (and such shifts likely never will be realistic, even with radical changes in government incentive programs and other factors). This conclusion is consistent with the finding of Jha et al. (2010a) who evaluated a different set of scenarios for the RRW with SWAT and also found that radical changes in management practices or cropping systems were needed to meet the TMDL goals. However, these results do provide insights into how environmental improvement can be realized for the RRW with modifications in current production approaches and also generally underscore the findings of the expert panel that targeted mixes of practices will be needed to meet RRW environmental goals, with variation in those mixes depending on the specific cropland landscape conditions and other factors.

One key weakness of the current modeling system was the absence of accounting for key "trapping practices" such as constructed wetlands and filter strips. But new or planned improvements in the current SWAT version 2012 (SWAT2012) code will provide for the potential to simulate such practices in a realistic manner for the RRW, if additional SWAT simulation scenarios are performed for the watershed in the future. In addition, there is a need to determine the most accurate overall nitrogen and phosphorus mass balances possible for the RRW. This is a key step in determining the total amount of nutrient inputs from fertilizer, manure, wastewater facilities and other sources. Considerable debate occurred during the course of this modeling study among members of the expert panel regarding the use of fertilizer in different situations, such as use of fertilizer on manure cropland, underscoring the need for obtaining as much actual data as possible regarding nutrient inputs and usage.

\section{Acknowledgement}

Appreciation is expressed to Ms. Jamie Ridgely and Agren, Inc. (http://www.agrentools.com/) for providing the subcontract (described below) to perform this work, for consultation provided by Ms. Ridgely and Mr. Adam Kiel (formally of the Iowa Department of Natural Resources and now with the Iowa Soybean Association) and to the expert panel members described in the study who provided guidance regarding the baseline management assumptions used in the SWAT modeling 
and also provided feedback regarding the modeling scenario results.

\section{Funding Information}

The Iowa Department of Natural Resources (DNR) awarded a grant to the Missouri \& Mississippi (M\&M) Divide RC\&D, with a subcontract to Agren, Inc., to develop a Water Quality Master Plan for the Raccoon River Watershed in January 2010. Funding for the grant agreement was provided through Section 319 of the Environmental Protection Agency, as well as Section 604(b) of the American Recovery and Reinvestment Act of 2009. The specific research reported in this study was funded in part via a subcontract with Agren, Inc., the U.S. Environmental Protection Agency's Targeted Watersheds Grants Program (Project \#WS97704801) and the National Science Foundation's Dynamics of Coupled Natural and Human Systems of the U.S. (Project \# DEB-1010259).

\section{Author's Contribution}

All of the authors made valuable contributions to this study.

\section{Ethics}

The information reported in this study is original research that has not been reported previously in any other scientific journal.

\section{References}

Agren, 2011. Raccoon River watershed water quality master plan. Agren, Inc. Carroll, IA.

Arnold, J.G. and N. Fohrer, 2005. SWAT2000: Current capabilities and research opportunities in applied watershed modelling. Hydrol. Proc., 19: 563-572. DOI: $10.1002 /$ hyp.5611

Arnold, J.G., R. Srinivasan, R.S. Muttiah and J.R. Williams, 1998. Large area hydrologic modeling and assessment part I: Model development. J. Am. Water Resources Association, 34: 73-89. DOI: 10.1111/j.1752-1688.1998.tb05961.x

Bressiani, D.D.A., P.W. Gassman, J.G. Fernandes, L.H.P. Garbossa and R. Srinivasan et al., 2015. A review of Soil and Water Assessment Tool (SWAT) applications in Brazil: Challenges and prospects. Int. J. Agric. Biol. Eng., 8: 1-27.

DOI: $10.3965 /$ j.ijabe.20150803.1765

Burkart, C. and M. Jha, 2007. Nitrate reduction approaches. Choices: Magazine Food Farm Resource, 22: 103-107.

DMWW, 2015. Fact sheet: Nitrate removal facility. Des Moines Water Works, Des Moines.
Douglas-Mankin, K.R., R. Srinivasan and J.G. Arnold, 2010. Soil and Water Assessment Tool (SWAT) model: Current developments and applications. Trans. ASABE, 53: 1423-1431. DOI: 10.13031/2013.34915

Du, B., A. Saleh, D.B. Jaynes and J.G. Arnold, 2006. Evaluation of SWAT in simulating nitrate nitrogen and atrazine fates in a watershed with tiles and potholes. Trans. ASABE, 49: 949-959. DOI: $10.13031 / 2013.21746$

Du, B., J.G. Arnold, A. Saleh and D.B. Jaynes, 2005. Development and application of SWAT to landscapes with tiles and potholes. Trans. ASABE, 48: 1121-1133. DOI: 10.13031/2013.18522

Di Luzio, M., J.G. Arnold and R. Srinivasan, 2004. Integration of SSURGO maps and soil parameters within a geographic information system and nonpoint source pollution model system. J. Soil Water Conservation, 59: 123-133.

Feng, H., M. Jha and P.W. Gassman, 2009. The allocation of nutrient load reduction across a watershed: Assessing delivery coefficients as an implementation tool. Rev. Agric. Eco., 31: 183-204. DOI: $10.1111 /$ j.1467-9353.2008.01432.x

Gassman, P.W. and J.K. Jha, 2011. Application of the Soil and Water Assessment Tool (SWAT) model for the Raccoon River watershed master plan. Submitted to AGREN Inc., Carroll, Iowa.

Gassman, P.W., A.M. Sadeghi and R. Srinivasan, 2014. Applications of the SWAT model special section: Overview and insights. J. Environ. Quality, 43: 1-8. DOI: $10.2134 /$ jeq2013.11.0466

Gassman, P.W., M.R. Reyes, C.H. Green and J.G. Arnold, 2007. The soil and water assessment tool: Historical development applications and future research directions. Trans. ASABE, 50: 1211-1250. DOI: $10.13031 / 2013.23637$

Gassman, P.W. and Y. Wang, 2015. IJABE SWAT Special Issue: Innovative modeling solutions for water resource problems. Int. J. Agric. Biol. Eng., 8: 1-8. DOI: 10.3965/j.ijabe.20150803.1763

Green, C.H., M.D. Tomer, M. Di Luzio and J.G. Arnold, 2006. Hydrologic evaluation of the soil and water assessment tool for a large tile-drained watershed in Iowa. Trans. ASABE, 49: 413-422. DOI: $10.13031 / 2013.20415$

Hatfield, J.L., L.D. McMullen and C.S. Jones, 2009. Nitrate-nitrogen patterns in the Raccoon River basin related to agricultural practices. J. Soil Water Conservation, 64: 190-199. DOI: 10.2489 /jswc.64.3.190

IDNR, 2008. Natural resources geographic information systems library. Iowa Department of Natural Resources, Iowa Geological and Water Survey, Iowa DNR. 
ISU, 2008. Iowa Environmental Mesonet: NWS Coop. Department of Agronomy, Iowa State University, Ames, Iowa.

Jha, M., J.G. Arnold and P.W. Gassman, 2007. Water quality modeling for the Raccoon River watershed using SWAT. Trans. ASABE, 50: 479-493. DOI: $10.13031 / 2013.22660$

Jha, M.K., C.F. Wolter, K.E. Schilling and P.W. Gassman, 2010a. Assessment of total maximum daily load implementation strategies for nitrate impairment of the raccoon river, Iowa. J. Environ. Quality, 39: 1317-1327. DOI: $10.2134 /$ jeq2009.0392

Jha, M., C.F. Wolter, K.E. Schilling and P.W. Gassman, 2010b. Assessment of total maximum daily load implementation strategies for nitrate impairment of the raccoon river, Iowa (Supplement 1). J. Environ. Quality, 39: 1317-1327. DOI: $10.2134 /$ jeq2009.0392

Krause, P., D.P. Boyle and F. Bäse, 2005. Comparison of different efficiency criteria for hydrological model assessment. Adv. Geosci., 5: 89-97. DOI: $10.5194 /$ adgeo-5-89-2005

Krysanova, V. and M. White, 2015. Advances in water resources assessment with SWAT-an overview. Hydrol. Sci. J., 60: 771-783. DOI: $10.1080 / 02626667.2015 .1029482$

Libra, R.D., C.F. Wolter and R.J. Langel, 2004. Nitrogen and phosphorus budgets for Iowa and Iowa watersheds. Iowa Department of Natural Resources-Geological Survey, 109 Trowbridge Hall, Iowa City, IA.

Miller, G.A., T.E. Fenton and B.J. Tiffany, 2006. Iowa soil properties and interpretations database: ISPAID version 7.0. Iowa State University.

Moriasi, D.N., J.G. Arnold, M.W. Van Liew, R.L. Binger and R.D. Harmel et al., 2007. Model evaluation guidelines for systematic quantification of accuracy in watershed simulations. Trans. ASABE, 50: 885-900. DOI: 10.13031/2013.23153

Neitsch, S.L., J.G. Arnold, J.R. Kiniry and J.R. Williams, 2005. Soil and water assessment tool theoretical documentation: Version 2005. Soil and Water Research Laboratory, Texas A\&M University.

Neitsch, S.L., J.G. Arnold, J.R. Kiniry, R. Srinivasan and J.R. Williams, 2004. Soil and water assessment tool input/output file documentation: Version 2005. Soil and Water Research Laboratory, Texas A\&M University.

Prior, J.C., 1991. Landforms of Iowa. Univ. of Iowa Press, Iowa City, Iowa.

Randall, G., D. Mulla, G. Rehm, L. Busman and J. Lamb et al., 2002. Phosphorus: Transport to and availability in surface waters. WW-06796, University of Minnesota.
Schilling, K.E., C.F. Wolter, D.E. Christiansen, D.J. Schnoebelen and M. Jha, 2008b. Water quality improvement plan for Raccoon River, Iowa. Watershed Improvement Section, Iowa Department of Natural Resources.

Schilling, K.E., M. Jha, Y.K. Zhang, P.W. Gassman and C.F. Wolter, 2008a. Impact of land use and land cover change on the water balance of a large agricultural watershed: Historical effects and future directions. Water Resources, Res. DOI: 10.1029/2007WR006644

Schilling, K.E., P.W. Gassman, C.L. Kling, T. Campbell and M.K. Jha et al., 2014. The potential for agricultural land use change to reduce flood risk in a large watershed. Hydrol. Proc., 28: 3314-3325. DOI: 10.1002/hyp.9865

Sharpley, A.N., P.J.A. Kleinman, R.W. McDowell, M. Gitau and R.B. Bryant, 2002. Modeling phosphorus transport in agricultural watersheds: Processes and possibilities. J. Soil Water Conservation, 57: 425-439.

Tuppad, P., K.R. Douglas-Mankin, T. Lee, R. Srinivasan and J.G. Arnold, 2011. Soil and Water Assessment Tool (SWAT) hydrologic/water quality model: Extended capability and wider adoption. Trans. ASABE., 54: 1677-1684. DOI: $10.13031 / 2013.34915$

USDA-NRCS, 2008a. Overview and history of hydrologic units and the Watershed Boundary Dataset (WBD). USDA, Natural Resources Conservation Service.

USDA-NRCS, 2008b. Soil Survey Geographic (SSURGO) data base. USDA, Natural Resources Conservation Service.

USGS, 2012. Federal Standards and Procedures for the National Watershed Boundary Dataset (WBD). Techniques and Methods 11-A3, Chapter 3 of Section A, Federal Standards Book 11, Collection and Delineation of Spatial Data, third ed. U.S. Department of the Interior, U.S. Geological Survey, Reston, VA and U.S. Department of Agriculture, Natural Resources Conservation Service, Washington, DC.

USGS, 2008b. National hydrography dataset. USGS, USDI.

USGS, 2008a. The national map viewer and download platform. USGS, USDI.

Williams, J.R., J.G. Arnold, J.R. Kiniry, P.W. Gassman and C.H. Green, 2008. History of model development at Temple, Texas. Hydrol. Sci. J., 53: 948-960. DOI: 10.1623 /hysj.53.5.948 